\title{
Penerapan Metode Analitycal Hierarchy Process (AHP) dalam Menentukan Judul Skripsi
}

\author{
Joko Syahputra ${ }^{1}$, Alex Rikki ${ }^{2}$ \\ STMIK Budi Darma Medan, Jl.Sisingamangaraja No.338 Simpang Limun Medan, Indonesia, \\ Universitas Imelda Medan, Jl. Bilal Ujung No.24,52, Pulo Brayan Darat I, Kec. Medan Tim., Kota Medan, Sumatera \\ Utara 20239. \\ Jokosyahputra26@gmail.com, alexrikisinaga@gmail.com
}

\begin{abstract}
Abstrak. Skripsi merupakan persyaratan untuk mendapatkan status sarjana (S1) di setiap Perguruan yang ada di Indonesia. Istilah skripsi sebagai tugas akhir sarjana hanya digunakan di Indonesia. Untuk menyelesaikan skripsi mahasiswa dituntut untuk menerapkan apa yang mereka pelajari kedalam sebuah aplikasi atau penerapan pada bidang tertentu baik pembelajaran, serta berbentuk aplikasi komputer. Analitical hierarcy process (AHP) adalah suatu teori umum tentang pengukuran yang digunakan untuk untuk sekala rasio, baik dari perbandingan berpasangan yang diskrit maupun kontinu. Analitical hierarcy process $(A H P)$ dapat menyederhanakan masalah yang kompleks dan tidak terstuktur, strategik dan dinamik menjadi bagianya, serta menjadikan variabel dalam suatu hieraki (tingkatan) metode Analitical hierarcy process (AHP) mempunyai kemampuan untuk memecahkan masalah yang multi-obyetif yang berdasarkan pada perbandingan preferensi dari setiap elemen dan hieracki.
\end{abstract}

Kata Kunci : Sistem Pendukung Keputusan, Penentuan Judul, Metode Analitical hierarcy process (AHP), Macromedia Dreamweaver

\begin{abstract}
Thesis is a requirement to obtain undergraduate status (S1) in every university in Indonesia. The term thesis as an undergraduate final project is only used in Indonesia. To complete the thesis, students are required to apply what they learn into an application or application in certain fields, both learning and in the form of computer applications. Analytical hierarchy process (AHP) is a general theory of measurement used for scale ratios, both from discrete and continuous pairwise comparisons. Analytical hierarchy process (AHP) can simplify complex and unstructured, strategic and dynamic problems into its parts, and make variables in a hierarchy (level) the Analytical hierarchical process (AHP) method has the ability to solve multi-objective problems based on comparisons preferences of each element and hierarchy.
\end{abstract}

Keyword : Decision Support System, Title Determination, Analytical Hierarchy Process (AHP) Method, Macromedia Dreamweaver

\section{PENDAHULUAN}

Skripsi merupakan persyaratan untuk mendapatkan status sarjana (S1) di setiap Perguruan Tinggi yang ada di Indonesia. Skripsi ini berkembang dan berfokus pada jurusan yang diambil saat kuliah, namun ketika memilih judul skripsi masih banyak mahasiswa mengalami kesulitan untuk menentukannya. Demikian pula dalam jurusan komputer masih banyak mahasiswa yang merasa kesulitan untuk menentukan judul skripsi yang sesuai karena kurangnya referensi yang dimiliki setiap mahasiswa dan tingkat kemampuan yang dimiliki mahasiswa tersebut.

Oleh karena itu mahasiswa sering sekali mengganti judul skripsinya di karenakan tidak sesuai dengan isi skripsi tersebut. Padahal banyak judul-judul skripsi yang bisa dimengerti dan diterima sesuai dengan kemampuan dan tingkat kesulitanya melalui Internet seperti: Sistem pendukung keputusan, Kriptografi, Pengolahan Citra, dan masih banyak lagi judul-judul skripsi tentang komputer yang bisa mahasiswa pahami dan mengerti.

Adapun manfaat dari penulisan skripsi ini mempermudah mahasiswa untuk menentukan judul skripsi yang sesuai dengan kemampuan mahasiswa, sebagai salah satu alternatif bagi mahasiswa untuk menentukan judul skripsi yang sesuai dengan keinginan dan kemampuan mahasiswa dan dapat membantu mahasiswa dalam mempertimbangkan judul yang sesuai dengan kemampuan yang dimiliki mahasiswa. 


\section{METODOLOGI PENELITIAN}

\subsection{Fuzzy Multiple Attribute Decision Making (FMADM)}

Fuzzy Multiple Attribute Decision Making (FMADM) adalah suatu metode yang digunakan untuk mencari alternatif optimal dari sejumlah alternatif dengan kriteria tertentu[1]. Inti dari Fuzzy Multiple Attribute Decision Making (FMADM) adalah menentukan nilai bobot untuk setiap atribut, kemudian dilanjutkandengan proses perankingan yang akan menyeleksi alternatif yang sudah diberikan[2].

Pada dasarnya, ada tiga pendekatan untuk mencari nilai bobot atribut, yaitu pendekatan subyektif, pendekatan obyektif dan pendekatan integrasi antara subyektif dan obyektif. Masingmasing pendekatan memiliki kelebihan dan kelemahan. Pada pendekatan subyektif, nilai bobot ditentukan berdasarkan subyektifitas dari para pengambil keputusan, sehingga beberapa faktor dalam proses perankingan alternatif dapat ditentukan secara bebas. Sedangkan pada pendekatan obyektif, nilai bobot dihitung secara matematis sehingga mengabaikan subyektifitas dari pengambil keputusan.

\subsection{Analytical Hierrchy Process (AHP)}

Metoda Analytical Hierrchy Process (AHP) dekembangkan oleh Prof. Thomas Lorie Saaty dari Wharton Business School di awal tahun 1970, yang digunakan untuk mencari rangking atau urutan prioritas dari berbagai alternatif dalam pemecahan suatu permasalahan[3]. Dalam kehidupan sehari-hari, seseorang senantiasa dihadapkan untuk melakukan pilihan dari berbagai alternatif. Disini diperlukan penentuan prioritas dan uji konsistensi terhadap pilihan-pilihan yang telah dilakukan. Dalam situasi yang kompleks, pengambilan keputusan tidak dipengaruhi oleh satu faktor saja melainkan multifaktor dan mencakup berbagai jenjang maupun kepentingan. Pada dasarnya Analytical Hierrchy Process (AHP) adalah suatu teori umum tentang pengukuran yang digunakan untuk menemukan skala rasio, baik dari perbandingan berpasangan yang diskrit maupun kontinu[4]. Perbandingan-perbandingan ini dapat diambil dari ukuran aktual atau skala dasar yang mencerminkan kekuatan perasaan dan preferensi relatif. Metode ini adalah sebuah kerangka untuk mengambil keputusan dengan efektif atas persoalan dengan menyederhanakan dan mempercepat proses pengambilan keputusan dengan memecahkan persoalan tersebut kedalam bagian-bagiannya, menata bagian atau variabel ini dalam suatu susunan hirarki, memberi nilai numerik pada pertimbangan subjektif tentang pentingnya tiap variabel dan mensintesis berbagai pertimbangan ini untuk menetapkan variabel yang mana yang memiliki prioritas paling tinggi dan bertindak untuk mempengaruhi hasil pada situasi tersebut[5].

\subsection{Kelebihan Analitycal Hierarchy Process (AHP)}

Adapun kelebihan dari metode Analitycal Hierarchy Process (AHP) ini yang nantinya memepermudah penyelesaian dalam perancangan adalah[6][7] :

1. Struktur yang berhirarki merupakan konsekuensi dari kriteria yang dipilih sampai pada subkriteria paling dalam.

2. Memperhitungkan validitas sampai dengan batas toleransi inkonsistensi berbagai kriteria dan alternatif yang dipilih oleh pengambil keputusan.

3. Memperhitungkan daya tahan atau ketahanan output analisis sensitifitas pengambilan keputusan.

Selain mempunyai kelebihan, metode Analytical Hierarchy Process (AHP) ini juga mempunyai banyak keuntungan dalam penggunaannya. menjelaskan beberapa keuntungan yang diperoleh dengan menggunakan metode AnalyticalHierarchy Process (AHP) pada proses pengambilan keputusan multi-kriteria. metode AnalyticalHierarchy Process (AHP) mempuyai kemampuan untuk memecahkan masalah yang multi-obyektif yang berdasarkan pada perbandingan preferensi dari setiap elemen dan hirarki[8]. 


\section{HASIL DAN PEMBAHASAN}

Dalam penentuan memberikan rekomendasi kepada mahasiswa tentang judul yang sesuai dengan keinginan mereka dan kemampuan mereka digunakan kriteria yang akan menjadi acuan dalam pengambilan keputusan memberikan judul yang tepat maupun kriteria-kriteria yang digunakan adalah sebagai berikut:

1. Jenis skripsi

2. Tingkat Kesulitan

3. Bidang Kemampuan

\subsection{Pembahasan}

Dalam menganalisa pendukung keputusan dengan menggunakan metode Analytical Hierarchy Process ( AHP), dapat diketahui dalam penentuan keputusan dilakukan dari beberapa proses, berikut pembahasan penyelesaian penentuan keputusan menggunakan metode Analytical Hierarchy Process ( AHP). adapun langkah langkah nya sebagai berikut[9], [10]:

1. Menentukan masalah dan solusinya

2. Menentukan tahap tahap menentukan judul skripsi dari level teratas

3. Menentukan kriteria kriteria yang diberikan dan mematrikskannya

4. Menjumlahkan nilai dari setiap kolom dan baris pada matriks serta membagi

Setiap matriks dari kolom, setelah itu dijumlahkan untuk mendapatkan nilai

Normalisasi.

5. Mengukur konsitensi dengan langkah awalnya :

a. Mengkalikan setiap nilai pada kolom pertama dengan prioritas relative elemen pertama, nilai pada kolom kedua dengan prioritas relative elemen kedua dan seterusnya.

b. Jumlahkan setiap baris.

c. Hasil penjumlahan tiap baris dibagi prioritas bersangkutan dan hasilnya dijumlahkan.

6. Mencari nilai Consistency Index dengan rumus $\mathrm{CI}=(\Omega$ maks $-\mathrm{n}) / \mathrm{n}-1$

Keterangan :

CI $=$ Consistency Index

Smaks = Eigenvalue maksimum

$\mathrm{n} \quad=$ banyak nya elemen

7. Mencari nilai Consistency Ratio

$\mathrm{CR}=\mathrm{CI} / \mathrm{RI}$

Keterangan :

$\mathrm{CR}=$ Consistency Ratio

$\mathrm{CI}=$ Consistency Index

$\mathrm{RI}=$ Random Index

8. Memeriksa konsistensi hirarki, yang diukur adalah rasio konsistensi dengan melihat index konsistensi. Jika Consistency Ratio < 0,1 maka nilai perbandingan berpasangan pada matriks kriteria yang diberikan konsisten.

Ada beberapa kriteria menentukan judul skripsi yang dibutuhkan oleh para mahasiswa adalah sebagai berikut :

1. Jenis skripsi $\quad=1$

2. Tingkat kesulitan $\quad=2$

3. Bidang kemampuan $=3$

Adapun nilai dari setiap kriteria tersebut diatas adalah :

1. Mudah

2. Sulit 
3. Sangat sulit

Dengan adanya nilai kriteria tersebut untuk mendapatkan nilai diperoleh dengan perkalian matriks.

1. Menentukan prioritas kriteria

a. Menentukan matriks perbandingan berpasangan disini dilakukan tahap penilaian perbandingan antara satu kriteria yang lain . dan hasil penilaian tersebut dapat dilihat sebagai berikut :

Table 1. Matriks Perbandingan Pasangan

\begin{tabular}{|c|c|c|c|}
\hline & Jenis skripsi & Tingkat kesulitan & Bidang kemampuan \\
\hline Jenis skripsi & 1 & 2 & 3 \\
\hline Tingkat kesulitan & 0.5 & 0.6 & 3 \\
\hline Bidang kemampuan & 0.8 & 0.2 & 6 \\
\hline Jumlah & 2.3 & 2.8 & 12 \\
\hline
\end{tabular}

Penyelesaian matriks perbandingan pasangan ini dengan membagikan setiap kolom dengan kolom berikutnya, untuk mendapatkan hasil matriks jenis skripsi yaitu nilai 1 dibagikan dengan kolom Jenis skripsi baris Tingkat kesulitan yaitu dapat hasil 0.5, untuk hasil kolom berikutnya bagikan kembali dengan kolom penampilan begitulah seterusnya.

b. Matriks nilai kriteria

Tabel 2. Matriks Nilai Kriteria

\begin{tabular}{|l|l|l|l|l|l|}
\hline & $\begin{array}{l}\text { Jenis } \\
\text { skripsi }\end{array}$ & $\begin{array}{l}\text { Tingkat } \\
\text { kesulitan }\end{array}$ & $\begin{array}{l}\text { Bidang } \\
\text { kemampuan }\end{array}$ & Jumlah & Prioritas \\
\hline Jenis skripsi & 0.43 & 0.71 & 0.25 & 1.39 & 0.46 \\
\hline Tingkat kesulitan & 0.21 & 0.21 & 0.25 & 1.67 & 0.55 \\
\hline $\begin{array}{l}\text { Bidang } \\
\text { kemampuan }\end{array}$ & 0.24 & 0.07 & 0.5 & 0.81 & 0.27 \\
\hline
\end{tabular}

Penyelesaiannya dengan Rumus :

Nilai matriks nilai kriteria = nilai baris kolom matriks perbandingan pasangan/jumlah dari kolom baris pertama. Contohnya :

Matrik nilai kriteria : $1: 2.3=0.43$ dan seterusnya

Untuk prioritas $=$ jumlah $:$ kriteria penentuan judul skripsi

Contohnya :

Prioritas $=1.39: 3=0.46$ dan seterusnya

c. Matriks penjumlahan setiap baris

Tabel 3. Matriks penjumlahan setiap baris

\begin{tabular}{|l|l|l|l|l|}
\hline & Mudah & Sulit & Sangat sulit & Jumlah \\
\hline Jenis skripsi & 0.46 & 1.1 & 0.81 & 2.37 \\
\hline Tingkat kesulitan & 0.23 & 0.33 & 0.81 & 1.37 \\
\hline Bidang kemampuan & 0.36 & 0.11 & 0.62 & 2.62 \\
\hline
\end{tabular}

Matriks ini dengan mengkalikan nilai prioritas dengan matriks perbandingan berpasangan. Matriksp enjumlahan $=$ Prioritas $:$ kolom Jenis skripsi di matriks perbandingan

Contohnya: $0.46: 1=0.46$

Begitu juga untuk nilai kolom berikutnya dan seterusnya 


\section{d. Perhitungan Ratio Konsitensi}

Untuk memastikan bahwa nilai rasio konsitensi $(\mathrm{CR})<=10$ untuk itu dibuat tabel sebagai berikut :

Tabel 4. Perhitungan Rasio konstitunsi

\begin{tabular}{|l|l|l|l|}
\hline & $\begin{array}{l}\text { Jumlah } \\
\text { perbaris }\end{array}$ & Prioritas & Hasil \\
\hline Jenis skripsi & 2.37 & 0.46 & 2.83 \\
\hline Tingkat kesulitan & 1.37 & 0.55 & 1.92 \\
\hline Bidang kemampuan & 2.62 & 0.27 & 2.89 \\
\hline
\end{tabular}

Penyelesaian :

Pada kolom jumlah perbaris diambil dari jumlah Matriks penjumlahan setiap baris

Dan untuk kolom prioritas diambil dari kolom matrik nilai kriteria. Rumusnya adalah sebagai berikut :

Dengan nilai jumlahan dari hasil :7.64

n (jumlah kriteria): 3

$\lambda$ maks (jumlah/n): 2.54

CI (( $\lambda$ maks-n $)-n):-0.68$

CR (CI/IR(lihat tabel 3.5)): -0.76

Oleh karena $\mathrm{CR}<0.1$, maka rasio konsistensi dari perhitungan tersebut bisa diterima.

Dalam hal ini, terdapat 3 kriteria yang berarti akan ada 4 perhitungan prioritas subkriteria. Menghitung kriteria sub sub kriteria dari kriteria Jenis skripsi. Langkah langkah yang dilakukan untuk menghitung proioritas sub kriteria dari kriteria jenis skripsi adalah sebagai berikut :

Adapun langkah- langkahnya adalah sebagai berikut :

1. Matriks perbandingan berpasangan kriteria jenis skripsi ini sama caranya dengan matriks perbandingan berpasangan yang sudah kita bahas diatas. Yaitu sebagai berikut :

Tabel 5. Matriks perbandingan berpasangan kriteria Jenis skripsi

\begin{tabular}{|l|l|l|l|}
\hline & Mudah & Sulit & Sangat sulit \\
\hline Mudah & 1 & 3 & 5 \\
\hline Sulit & 0.33 & 1 & 3 \\
\hline Sangat sulit & 0.2 & 0.33 & 1 \\
\hline Jumlah & 1.53 & 4.33 & 9 \\
\hline
\end{tabular}

2. Membuat matriks Nilai kriteria jenis skripsi

Langkah yang ini pun sama dengan penyelesaian matrik kriteria pada tabel 6 diatas, ada tambahan prioritas .

Tabel 6. Matriks nilai kriteria jenis skripsi

\begin{tabular}{|l|l|l|l|l|l|l|}
\hline & Mudah & Sulit & $\begin{array}{l}\text { Sangat } \\
\text { Sulit }\end{array}$ & Jumlah & Prioritas & $\begin{array}{l}\text { Prioritas } \\
\text { Sub kriteria }\end{array}$ \\
\hline Mudah & 0.65 & 0.69 & 0.56 & 1.90 & 0.63 & 1 \\
\hline Sulit & 0.22 & 0.23 & 0.33 & 0.78 & 0.26 & 0.41 \\
\hline Sangat sulit & 0.13 & 0.08 & 0.11 & 0.32 & 0.11 & 0.17 \\
\hline
\end{tabular}

Prioritas sub kriteria didapatkan dari hasil nilai tertinggi pada kolom prioritas.

3. Matriks penjumlahan setiap baris

Sama dengan langkah pada matriks diatas pada tabel 7

Tabel 7. Matriks penjumlahan setiap baris kriteria Jenis skripsi 


\begin{tabular}{|l|l|l|l|l|}
\hline & Mudah & Sulit & Sangat sulit & Jumlah \\
\hline Mudah & 0.63 & 0.78 & 0.53 & 1.94 \\
\hline Sulit & 0.21 & 0.26 & 0.32 & 0.79 \\
\hline Sangat sulit & 0.13 & 0.09 & 0.11 & 0.32 \\
\hline
\end{tabular}

4. Perhitungan Rasio konsistensi

Penyelesaiannya sama dengan matrik rasio konsistensi yang telah kita bahas diatas, untuk memastikan nilai Rasio $(\mathrm{CR})<=0.1$

Tabel 8. Penghitungan Rasio Konsistensi

\begin{tabular}{|l|l|l|l|}
\hline & Baris & Prioritas & Hasil \\
\hline Mudah & 1.94 & 0.63 & 2.58 \\
\hline Sulit & 0.79 & 0.26 & 1.05 \\
\hline Sangat sulit & 0.32 & 0.11 & 0.42 \\
\hline
\end{tabular}

5. Membuat matriks perbandingan berpasangan

Tabel 9. Perbandingan Berpasangan Kriteria Tingkat kesulitan

\begin{tabular}{|l|l|l|l|}
\hline & Mudah & Sulit & Sangat Sulit \\
\hline Mudah & 1 & 2 & 6 \\
\hline Sulit & 0.5 & 1 & 2 \\
\hline Sangat Sulit & 0.17 & 0.5 & 1 \\
\hline Jumlah & 1.67 & 3.5 & 9 \\
\hline
\end{tabular}

6. Membuat Matriks Nilai Kriteria

Tabel 10. Matriks Nilai Kriteria Tingkat kesulitan

\begin{tabular}{|l|l|l|l|l|l|l|}
\hline & Mudah & Sulit & Sangat sulit & Baris & Prioritas & $\begin{array}{l}\text { Prioritas } \\
\text { Subprioritas }\end{array}$ \\
\hline Mudah & 0.60 & 0.57 & 0.67 & 1.84 & 0.61 & 1 \\
\hline Sulit & 0.30 & 0.29 & 0.22 & 0.81 & 0.27 & 0.44 \\
\hline Sangat sulit & 0.10 & 0.14 & 0.11 & 0.136 & 0.12 & 0.19 \\
\hline
\end{tabular}

7. Matriks Penjumlahan

Tabel 11. Penjumlahan Setiap Baris Kriteria Tingkat Kesulitan

\begin{tabular}{|c|c|c|c|c|}
\hline & \multicolumn{1}{|l|}{ Mudah } & \multicolumn{1}{|l|}{ Sulit } & Sangat sulit & Jumlah \\
\hline Mudah & 0.61 & 0.54 & 0.71 & 1.86 \\
\hline Sulit & 0.31 & 0.27 & 0.24 & 0.81 \\
\hline Sangat sulit & 0.10 & 0.13 & 0.12 & 0.36 \\
\hline
\end{tabular}

8. Perhitungan Rasio Konsistensi

Tabel 12. Perhitungan Rasio Konsistensi Kriteria Tingkat Kesulitan

\begin{tabular}{|c|c|c|c|}
\hline & $\begin{array}{c}\text { Jumlah per } \\
\text { baris }\end{array}$ & Prioritas & Hasil \\
\hline Mudah & 1.86 & 0.61 & 2.47 \\
\hline Sulit & 0.81 & 0.27 & 1.08 \\
\hline Sangat Sulit & 0.36 & 0.12 & 0.48 \\
\hline
\end{tabular}

Jumlah (jumlahan dari nilai-nilai hasil): 4.03

$\mathrm{n}$ (jumlah kriteria): 3

$\lambda$ maks (jumlah/n): 1.34 
CI $((\lambda$ maks-n)/(n-1)): -0.55

CR (CI/IR(lihat tabel 3.5)): -0.95

Untuk penyelesaian kriteria bidang kemampuan sama halnya dengan Jenis skripsi

9. Matriks Perbandingan Berpasangan

Tabel 13. Matriks Perbandingan berpasangan Kriteria Bidang Kemampuan

\begin{tabular}{|c|c|c|c|}
\hline & Mudah & Sulit & Sangat Sulit \\
\hline Mudah & 1 & 3 & 4 \\
\hline Sulit & 0.33 & 1 & 3 \\
\hline Sangat Sulit & 0.25 & 0.35 & 1 \\
\hline Jumlah & 1.58 & 4.33 & 8 \\
\hline
\end{tabular}

10. Menentukan matriks nilai kriteria

Tabel 14. Matriks nilai Kriteria Bidang Kemampuan

\begin{tabular}{|l|r|r|r|r|r|c|}
\hline & \multicolumn{1}{|l|}{ Mudah } & \multicolumn{1}{|l|}{ Sulit } & \multicolumn{1}{l|}{$\begin{array}{l}\text { Sangat } \\
\text { Sulit }\end{array}$} & \multicolumn{1}{l|}{ Baris } & Prioritas & $\begin{array}{c}\text { Prioritas } \\
\text { Sub } \\
\text { kriteria }\end{array}$ \\
\hline Mudah & 0.63 & 0.69 & 0.50 & 1.83 & 0.61 & 1 \\
\hline Sulit & 0.21 & 0.23 & 0.38 & 0.81 & 0.27 & 0.45 \\
\hline Sangat Sulit & 0.16 & 0.08 & 0.13 & 0.36 & 0.12 & 0.20 \\
\hline
\end{tabular}

11. Menentukan matriks penjumlahan tiap baris

Tabel 15. Matriks Penjumlahan Kriteria Bidang Kemampuan

\begin{tabular}{|c|r|r|c|c|}
\hline & \multicolumn{1}{|c|}{ Mudah } & \multicolumn{1}{|l|}{ Sulit } & Sangat Sulit & Jumlah \\
\hline Mudah & 1.90 & 0.81 & 0.48 & 1.90 \\
\hline Sulit & 0.20 & 0.27 & 0.36 & 0.83 \\
\hline Sangat Sulit & 0.15 & 0.09 & 0.12 & 0.36 \\
\hline
\end{tabular}

12. Perhitungan rasio konsistensi

Tabel 16. Perhitungan rasio konsistensi Bidang kemampuan

\begin{tabular}{|l|c|r|l|}
\hline & Jumlah PerBaris & Prioritas & Hasil \\
\hline Mudah & 1.90 & 0.61 & 2.51 \\
\hline Sulit & 0.83 & 0.27 & 1.10 \\
\hline Sangat Sulit & 0.36 & 0.12 & 0.48 \\
\hline
\end{tabular}

Jumlah (jumlahan dari nilai-nilai hasil): 3.11

n (jumlah kriteria): 3

$\lambda$ maks (jumlah/n): 1.37

CI ( $(\lambda$ maks-n $) /(n-1)):-0.54$

CR (CI/IR(lihat tabel 3.5)): -0.94

Prioritas hasil perhitungan pada langkah menentukan prioritas kriteria : 
Tabel 17. .Matriks Hasil

\begin{tabular}{|c|c|c|}
\hline Jenis Skripsi & Tingkat Kesulitan & $\begin{array}{c}\text { Bidang } \\
\text { Kemampuan }\end{array}$ \\
\hline 0.42 & 0.27 & 0.19 \\
\hline Sulit & Sulit & Sulit \\
\hline 1 & 1 & 1 \\
\hline Mudah & Mudah & Mudah \\
\hline 0.41 & 0.44 & 0.45 \\
\hline Sangat Sulit & Sangat Sulit & Sangat Sulit \\
\hline 0.17 & 0.19 & 0.20 \\
\hline
\end{tabular}

dan kemudian menentukan sub kriteria dan dituangkan dalam matriks hasil.

Tabel diatas adalah hasil dari prioritas 1 dan 2 .

Ada 3 data nilai pada Penentuan Judul Skripsi seperti yang terlihat diatas maka hasil akhirnya akan tampak sebagai berikut:

Tabel 18. Menentukan Nilai Judul skripsi

\begin{tabular}{|c|c|l|l|}
\hline & Jenis Skripsi & \multicolumn{1}{|c|}{$\begin{array}{c}\text { Tingkat } \\
\text { Kesulitan }\end{array}$} & $\begin{array}{l}\text { Bidang } \\
\text { Kemampuan }\end{array}$ \\
\hline Pengolahan citra & Sulit & Sulit & Mudah \\
\hline SPK & Sangat sulit & Mudah & sulit \\
\hline Kriptografi & Mudah & Sulit & sulit \\
\hline
\end{tabular}

Tabel 19. Hasil akhir

\begin{tabular}{|c|c|c|c|r|}
\hline & Jenis Skripsi & $\begin{array}{l}\text { Tingkat } \\
\text { Kesulitan }\end{array}$ & $\begin{array}{l}\text { Bidang } \\
\text { Kemampuan }\end{array}$ & Total \\
\hline Pengolahan Citra & 0.17 & 0.12 & 0.19 & 0.60 \\
\hline SPK & 0.42 & 0.05 & 0.08 & 0.63 \\
\hline Kriftografi & 0.17 & 0.27 & 0.19 & 0.75 \\
\hline
\end{tabular}

Nilai 0.17 pada kolom baris Pengolahan Citra diperoleh dari nilai SPK, yaitu cukup dengan prioritas 0.41 (Tabel 3.22). dikalikan dengan prioritas jenis skripsi dengan nilai terbesar 0.42 (Tabel 3.22). Dari uraian tabel diatas sudah jelas bahwasanya semakin besar nilainya maka semakin sulit dalam menentukan Judul Skripsi. Dengan ini sudah dapat ditentukan bahwasanya Kriptografi yang Sangat sulit dalam menentukan judul skripsi.

\section{KESIMPULAN}

Dari hasil yang penulis lakukan terhadap penelitian ini penulis dapat menarik beberapa kesimpulan yang terkait dengan proses penelitian maupun dengan isi dari penelitian itu sendiri, kesimpulan-kesimpulan yang didapatkan dalam penulisan ini adalah :

1. Sistem yang sedang berjalan pada PT. SS Finance telah menggunakan sistem komputerisasi namun penulis melihat penerapan teknologi informasi masih belum secara keseluruhan terutama dalam pengambilan keputusan pemberian kredit kepada calon nasabah yang masih menggunakan buku sebagai alat untuk mencatat data-data calon nasabah yang telah memenuhi kriteria untuk mendapatkan kredit.

2. Sistem pendukung keputusan pemilihan calon nasabah ini mampu mendapatkan penerima yang layak mendapatkan kredit. Pengambilan keputusan dihitung menggunakan metode Technique for Other Preference by Similarity to Ideal Solution (TOPSIS).

3. Hasil perhitungan topsis yang diterapkan ini akan menghasilkan keluaran nilai intensitas prioritas calon nasabah tertinggi sehingga dapat diketahui yang calon nasabah memiliki nilai 
tertinggi yang layak untuk mendapatkan kredit..

\section{DAFTAR PUSTAKA}

[1] A. Rikki, "Pengujian Sistem Pendukung Keputusan Metode Simple Additive Weighting dan Weighted Product dengan Matlab," Media Inf. Anal. dan Sist., vol. 2, no. 1, 2017.

[2] A. Rikki, M. Maebun, and J. R. Siregar, "Sistem Pendukung Keputusan Penerimaan Karyawan Dengan Metode SAW Pada PT. Karya Sahata Medan,” J. Informatics Pelita Nusant., 2016.

[3] Tsabit Rahman dkk., "Analisis Model Pengambil Keputusan AHP dan TOPSIS Untuk memilih Software Berbasis Open Source Digital Library pada Universitas Janabadra," Semin. Nas. Inov. Teknol. UN PGRI Kediri, 22 Februari 2017, 2017.

[4] A. Setiyadi and R. D. Agustia, "Penerapan Metode AHP Dalam Memilih Marketplace ECommerce Berdasarkan Software Quality and Evaluation ISO/IEC 9126-4 Untuk UMKM,” J. IKRA-ITH Inform., 2018.

[5] R. S. Ilhami and D. Rimantho, "Penilaian Kinerja Karyawan dengan Metode AHP dan Rating Scale,” J. Optimasi Sist. Ind., 2017, doi: 10.25077/josi.v16.n2.p150-157.2017.

[6] Y. Sa'adati, S. Fadli, and K. Imtihan, "Analisis Penggunaan Metode AHP dan MOORA untuk Menentukan Guru Berprestasi Sebagai Ajang Promosi Jabatan,” SinkrOn, 2018.

[7] G. S. Mahendra and K. Y. Ernanda Aryanto, "SPK Penentuan Lokasi ATM Menggunakan Metode AHP dan SAW," J. Nas. Teknol. dan Sist. Inf., 2019, doi: 10.25077/teknosi.v5i1.2019.49-56.

[8] R. Umar, A. Fadlil, and Y. Yuminah, "Sistem Pendukung Keputusan dengan Metode AHP untuk Penilaian Kompetensi Soft Skill Karyawan," Khazanah Inform. J. Ilmu Komput. dan Inform., 2018, doi: 10.23917/khif.v4i1.5978.

[9] rani irma handayani and yuni darmianti, "Sistem Pendukung Keputusan Pemilihan Supplier Dengan Metode Analytical Hierarchy Process Pada Pt. Cipta Nuansa Prima Tangerang," J. Techno Nusa Mandiri, 2017.

[10]M. R. Ridha, "Model Analytical Hierarchy Process Untuk Penilaian Desa Dalam Program Desa Maju Inhil Jaya," SISTEMASI, 2018, doi: 10.32520/stmsi.v6i1.21. 